\title{
石綿代替繊維を用いたスレートの開発研究 STUDY ON DEVELOPMENT OF SLATES MADE OF ASBESTOS SUBSTITUTIVE FIBERS
}

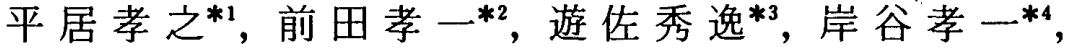 \\ 堀内盛夫*5, 林 雅治*6 \\ Takayuki HIRAI, Koichi MAEDA, Shuitsu YUSA, \\ Koichi KISHITANI, Morio HORIUCHI and Masaharu HAYASHI
}

Fibers which we used for asbestos substitutive materials are poly-vinyl-alcohol (Vinylon) fiber, poly-acrylo-nitorile (acrylic) fiber, and alkali-resistant glass fiber.

We used mini-Hatschek machine to make test products. We used cellulose fiber to hold cement particles and mineral.materials such as mica, cepiolite, wollastonite, silica fume, and bentonite, to prevent cracking and excessive length change.

We have done five tests for asbestos substitutive materials, which are on bending strength, freezing and thawing resistance, impulse resistance, Incombustibility, and fiber contents.

As a result, bending strength of asbestos alternative is a little low, but other properties of those are equal or better than asbestos slates.

Addition of $2 \%$ or $4 \%$ asbestos to alternatives did not make proprieties better compared to non asbestos alternatives exept product cost.

Keywords : asbestos substitutive fibers, asbestos alternatives, fiber content, bending strength, freezing and thawing resistance, incombustibility アスベスト代替瀻維，アスベスト代替品，繊維量，曲げ強さ，耐凍結融解性，難然性

\section{1.・まえがき}

石綿は，人体に吸入された場合に有害な物質として， 安全対策が強化されつつある。我が国では昭和 50 年に 労㗢安全衛生法に基づく管理物質に指定され，とくに作 業労働者への悪影響が懸念された吹付け石綿の使用が禁 止された。その後，教育施設に施工された石綿の人体へ の影響がマスコミ等で報道され社会的な関心が高まった こともあり，平成元年に一般環境への排出規制を目的と した大気污染防止法が改正された。

石綿製品の製造，施工，利用，廃棄の各段階における 安全性を高めるためには，石綿の代替化，含有量の低減 化を推進しここれらを通じて石綿使用の総量の低減化を 図ることが必要である。平成元年度に通商産業省に石䄸 対策検討委員会が設けられ，石綿製品の実態調査を行っ
て，石綿の代替と低滅の推進方法を検討するとともに， 石綿粉塵発生抑制マニュアルが作成された。

平成 2 年度はこれらの検討結果を踏まえ，石綿の代替 化などの施策を実効のあるものにするため，通商産業省 が財団法人建材試験センターに「石綿代替製品調查研究」 の委託を行った。委託研究は，代替化が遅れている中小 の石綿スレート製品製造メ一カーに石綿代替製品を製造 する際の指針となるガイドラインを示すことを目的と し，石䄸スレート製造メ一カーが現在使っている抄造装 置と供給可能な原材料を用いてスレートを製造する方法 の開発をテーマとして実施された。本論文はその研究結 果をまとめたものである。

\footnotetext{
*1 大分大学 教授 $\cdot$ 工博

*2 千葉大学 助教授. 工博

*3 建設省建築研究所第五研究部·防火材料研究室長· 工博

*4 日本大学 教授 東京大学名誉教授・工博

*5 ユニチ力

*6 日本電気硝子
}

Prof., Oita Univ., Dr. Eng

Assoc. Prof., Chiba Univ., Dr. Eng.

Building Research Institute, Dr. Eng.

Emeritus Prof., Tokyo Univ., Prof., Nihon Univ., Dr. Eng. Unitica Ltd. Nippon Electric Glass Co. Ltd. 
表一1 文献に取り上げられた石綿代替材料1-14)

\begin{tabular}{|c|c|c|c|c|c|}
\hline 系袐䊒材料 & 合成有機系維維材料 & 無 & 䅧 & 料 & 鉝 \\
\hline \multirow{5}{*}{ 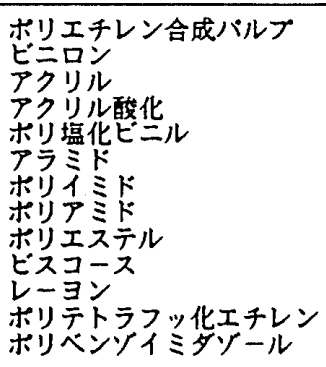 } & \multirow{2}{*}{ 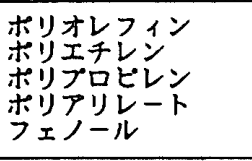 } & \multirow{5}{*}{ 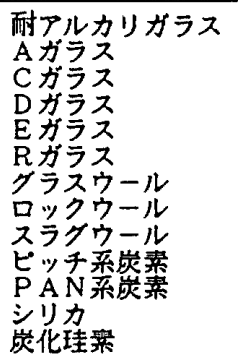 } & \multirow{5}{*}{ 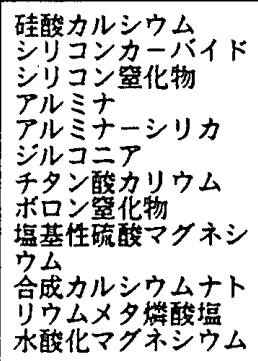 } & 石雪 & \multirow{3}{*}{ 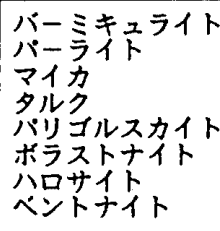 } \\
\hline & & & & 物 & \\
\hline & 天然有機系絰䊒材料 & & & $\begin{array}{l}\text { エリオナイト } \\
\text { P多バルジャト }\end{array}$ & \\
\hline & \multirow{2}{*}{$\begin{array}{l}\text { セルロースバルフ } \\
\text { セルロース } \\
\text { サイザル } \\
\text { シュート } \\
\text { やしの果皮 }\end{array}$} & & & 七ピオライ & 金属槽椎 \\
\hline & & & & 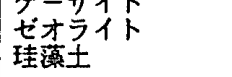 & $\begin{array}{l}\text { スチール } \\
\text { ステンレス }\end{array}$ \\
\hline
\end{tabular}

\section{2. 石綿代替材料に関する文献調査}

\section{1 スレート用石綿代替の材料}

石綿代替の可能性がある繊維材料として文献に取り上 げられてその物性が検討されている材料には，表一1の ようなものがある(1) 14)。これらのうち，スレート用の石 綿代替材料としては, 補強用の瀻維材料のほか, 製造時 の抄造性を向上するための材料之成形後の寸法安定性を 改善するための混和材料が対象になる。

補強用の繊維材料としては, 強度, 弾性, セメントマ トリックス中での耐久性, 耐熱性のほか, 抄造時に受け る物理的損傷に対する抵抗性や価格が問題となる。

ビニロン瀻維は，七メント補強用に使うことを目的と して, 強度と弾性率が通常の製品より大きな高強力タイ プの特殊ビニロンが製造されている。

アクリル瀻維は，従来の製品を改質して高強度と高弾 性率を付与し, 耐アルカリ性, 耐酸性能, 耐候性, およ び耐光性を向上してセメント補強に適するようにした種 類が製造されている。

耐アルカリガラス瀻維はセメント系材料の補強に実績 があり, 最近ではジルコニアの含有量を高めて耐アルカ リ性をさらに向上した種類が製造されている。

以上の 3 種類以外でセメント補強に使える繊維材料は 少なくないが，スレート用の補強瀻維としては価格や補 強効果の点で使える見込みがない。例えば炭素繊維は高 強度高弾性で大きな補強効果があり，また耐薬品性に優 れており，セメント補強用に使われた実績があり，さら に最近では以前より低価格の製品が製造されているが， それでも現時点ではスレート用としてはかなり高価格で ある。

抄造によるスレートの製造では, 多量の水にサスペン ジョンとして混合している緎維材料やセメントをすき上 げてマット状にし，それを压密して脱水する工程で，七 メント粒子をホルディングして流出させないようにしな ければならない。そのための材料として高叨解された織 維材料が必要である。高吒解の緎維材料としてはセル ロースパルプと，ポリエチレン合成パルプが製造されて いる。前者は天然植物㵶維を加工したものであり，比較
的安価で有望な材料であり，セメント補強に使われた実 績が多い。後者は耐水性, 耐薬品性, 耐油性にすぐれ, 耐候性があるが価格が前者よりかなり高くスレート用と してはコストが問題になる。

寸法安定性とひび割れ防止のために混和する材料とし て, マイカ, セピオライト, ワラストナイト, アタパル ジャイト，エリオナイトなどの鉱物が適しており，セメ ント製品の混和材料としての使用の実績がある。これら の材料は緎維状の形態をしているものもあるが，セメン 卜との付着性が小さいので補強効果は低い。

\section{2 代替材料を用いた場合の性能}

2.1 で述べたスレート用の石綿代替材料に関し，従来 の研究で調べられていることは以下のようである。

セルロース繊維をセメント補強に使うと, 中性化によ り繊維とマトリックスの界面の密度増加と, 繊維の石質 化が起こり, 強度と弾性係数が増加するが, 温湿度を変 えた促進試験により, 強度が低下する ${ }^{16)}$ 。オートクレー ブ養生すると，加熱あるいは乾湿繰り返しによる強度低 下は少なく, 自然暴露で強度の低下は認められず，さら に木材腐朽菌の培地で腐朽させても強度の低下はなく， また石質化が少ない(15),17)。

麻パルプと合成瀻維を用いた場合は，排水中の固形成 分の濃度が高く，繊維分散が悪いなど抄造性が劣り，ま た曲げ強度と㔀離強度が低く寸法安定性が十分でなく製 品としての性能が低い。この理由はパルプの叨解による フィブリル化が十分でなく，またワラストナイトや高分

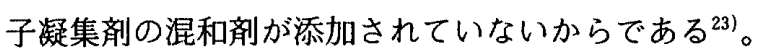

ビニロン瀻維とセルロースパルプを用いて抄造設備で 作製したスレートは，作製直後に曲げ試験をすると多数 の亀裂が入り瀻維との付着が不良となり瀻維の引き抜け と破断が起きるが，長期材令の試験体では付着の不良と 瀻維の引き抜けが明らかに娍少して強度とねばり強さが 増加し，自然暴露の試験体では繊維とマトリックスの界 面で付着が向上し試験体の強度が増加する ${ }^{18)}$.199。またビ ニロン繊維は $80^{\circ} \mathrm{C}$ までセメントの高アルカリ性に対し 耐久性があり，かつ抄造過程での損傷がない。養生条件 によっては材令とともにビニロン緎維の変化が X 線回 
折により観察される場合もあるが，試験体の曲げ強度に 影響はない吕。

セメント補強に適するように改質したアクリル瀻維と セルロースパルプを用いた場合は，ドイツの規格で有害 ガスを発生しない不然材料に認定できるものが作製で き,さらに少量の合成瀻維を入れると，曲げ破壊断面で 繊維の引き抜けがなく石綿スレートに比べてやや低い強 度とより大きな変形性能が得られる221。

ビニロン繊維または耐アルカリガラス繊維とパルプを 用いた場合は，繊維の分散は良好であるが連続抄造にお いて従来の石綿スレートの場合より抄造効率の低下が予 測される。補強効果はビニロン䋐維と耐アルカリガラス 緎維で差は無く,たわみ, 耐衝撃性については,ビニロ シがやや優れている。また長期耐久性はビニロンのほう が若干良い。ただし，オートクレーブ養生では両纎維よ も現状の調合では補強効果を期待できない211。

抄造性, 補強効果, ヤング率, 耐衝撃性においてビニ ロン綫維のほうが, 耐アルカリガラス瀻維とポリプロピ レン瀻維より優れている24)。

石綿含有量を $5 \%$ に減らして, パルプと耐アルカリ ガラス繊維とポリプロピレン繊維を用いてスレートを作 製すると, 成形上の問題は無く, 規格値を満足する性能 が得られ，また水中浸漬と大気暴露において強度低下は 観察されない25)。

\section{3 代替材料の有害性}

石綿代替の必要性は, 発ガン性という人体への有害性 が原因であり，石綿代替材料の適用においてもその有害 性について十分検討しておかねばならない。代替材料の 有害性を検討する上で参考となるこれまでの研究をまと めると以下のようである。

\subsection{1 繊維の有害性に関する一般論}

1977 年に Stanton が動物実験から, 緎維の種類にか かわらず太さ $1.5 \mu \mathrm{m}$ 末満長さ $8 \mu \mathrm{m}$ 以上の繊維で腫瘍 の発生率が高いことを発表した。Pott 等にようてこの ことが追試され，人の体内で不溶性で長く細い繊維にお いて，腫㾴発生能が強いことが立証された。ただし，エ リオナイトのように，この範囲のサイズではない繊維に おいても悪性中皮種発生の報告はある27)。

長さ $8 \mu \mathrm{m}$ 以下の繊維は, 胸膜に移植後, 食細胞の食 作用により食べられるので, 催腫瘍性または発ガン作用 は小さい。長さ $8 \mu \mathrm{m}$ 以上の織維では, 長さが長くなる ほど，また径が数ミクロン以下のものでは径が太くなる ほど, 1 本の繊維当たりの発ガン性と催腫煬性の可能性 は増加する ${ }^{28)}$ 。

発ガン性は食細胞の食作用をのがれる繊維の表面積に 比例すると考えられ，それゆえ，繊維 1 本当たりの危険 性は, 長さが約 $8 \mu \mathrm{m}$ 以下の繊維では非常に低いが, 長 い瀻維では瀻維 1 本当たりの影響は, 一定の径以下では
長さと径の積に比例するということが示唆されてい $ろ^{28)}$ 。

繊維のサイズが肺胞への沈着を左右する。ラットでは 瀻維径が $1 \mu \mathrm{m}$ を超えると吸入性が低下し, 人の口呼吸 では繊維径が $5 \mu \mathrm{m}$ を超えると, 吸入性が著しく低下す る。 $5 \mu \mathrm{m}$ 以下の長さの纎維は肺胞でマクロファージに より効率良く除去されるが，10 $\mu \mathrm{m}$ より長くなると除去 の効率が大きく低下する。データは少ないが, 繊維の他 の器官への移転は限定されている29)。

ガンになりやすい瀻維の特性としては，数力月は動物 の組織に存続すること, また径が $5 \mu \mathrm{m}$ 以下で長さが 5 $\mu \mathrm{m}$ 以上であることである ${ }^{30)}$ 。

発ガン性がある繊維は, 細くて体内に吸引され得るこ と, 長くて体内に物理的に滞留し得ること, 生体内で安 定して存在できる化学構造であることの 3 点の特性をも つ)。

皮膚や目のかゆみはロックウール，スラグウール，連 続ガラス繊維のような $5 \mu \mathrm{m}$ 程度以上の直径をもつ瀻維 により起こる。じんましん, 湿掺などを起こすが, 皮膚 炎は重症でないる11。

\subsection{2 スレート用石綿代替材料の有害性}

先に示したスレート用石綿代替材料の有害性につい て, 文献調查から次の事が言える ${ }^{14), 26)-34 \text { 。 }}$ セルロースパルプ, ビニロン繊維, アクリル繊維につ いては，人体に対して何らかの有害性を報告する文献が ない。

ガラス繊維については, 人体に発ガン性があるとは断 定できないが，人体への何らかの有害性を示唆する文献 が少なからずある。径の小さいガラス瀻維は, 同じ寸法 の石綿繊維と比較できるほどの細胞毒性を持つ危険性が あり，吸入される寸法のガラス繊維は，人の肺に石綿と 類似の影響を有する可能性がある。

マイカは，縬維症の原因となるトレモライトやクリソ タイルを含む可能性がある。

ワラストナイトは, 試験管内の試験により細胞系に対 して比較的無毒である。生物学的作用はあるが, 他のも のより少ない。

セピオライトは，結晶末端に有機イオンと有極性有機 物を吸着する特性がある。吸入した場合ラットにおいて 線維症が認められている。

シリカを含む材料は, 珪肺症を起こす可能性がある。

\section{3. 石綿代替材料を用いたスレートの試作}

\section{1 試験に用いた石綿代替材料}

文献調查より石綿代替の補強繊維としては, 合成有機 繊維のうちからセメントとの付着が良く, 引張強度亡弾 性率が比較的大きなビニロン瀻維とアクリル瀻維を選 び，また人造鉱物繊維のうちからセメント補強に有効な 
引張強度と弾性率を有する耐アルカリガラス瀻維を用い た。また抄造による成形において，七メント粒子のホル デングの役目のため高吒解したセルロースパルプを用 い, 比表面積の大きい耐熱・化学的安定フィラーの混和 材料としてマイカ, セピオライト，ワラストナイト，シ リカフュームまたはベントナイトなどを用いた。

これらの材料は，スレート製造の原材料として使われ るようになった場合の需要を満たすだけの量が供給でき る。試験に用いた材料の詳細を表一2に示す。

\section{2 調 合}

表一 3 に示す 9 種類の調合について試験体を試作し た。少量の石綿を混入すると諸性質が向上しコスト低減 に有利であると言われており，スレート協会が目標とし ている石䄸含有率の低減後の目標值が $5 \%$ 以下である ことから，無石綿の試験体のほかに石綿を $2 \%$ または $4 \%$ 混入した試験体を対象とした。また比較のための 基準品として石綿スレートのフレキシブル板と波板, 既
開発の無石綿製品についても試験体を用意した。なお基 準品の波板の試験体は，波の形を付ける前の平らな板状 で成形したものを用い, 他の種類の試験体と同じ寸法形 状である。

\section{3 試験体の作製}

ビニロン瀻維を補強瀻維とするVP-1，2，3 の試験体 は，ミニハチェック抄造機を用いて作製した。水，パル プ, 石綿, セピオライト, ワラストナイト, シリカフュー ム, ビニロン, マイカ, セメントの順で, 必要な材料を パルパーに投入して摫汼した。スラリーをチェストに投 入後 15 分で抄板を開始した。なお，抄造性向上のため 高分子凝集剤を添加し，抄板生板はビニールで包み，数 週間室内養生を行った。

アクリル繊維を補強繊維とする AP-1, 2, 3 の試験体 は，ミニハチェック抄造機を用いて作成した。パルパー 中に水之吒解パルプを投入して十分に摫挥した後，石綿 を入れる場合は石綿を投入して 10 分間摫汼を行い，さ

表一2 試験体作成に用いた材料

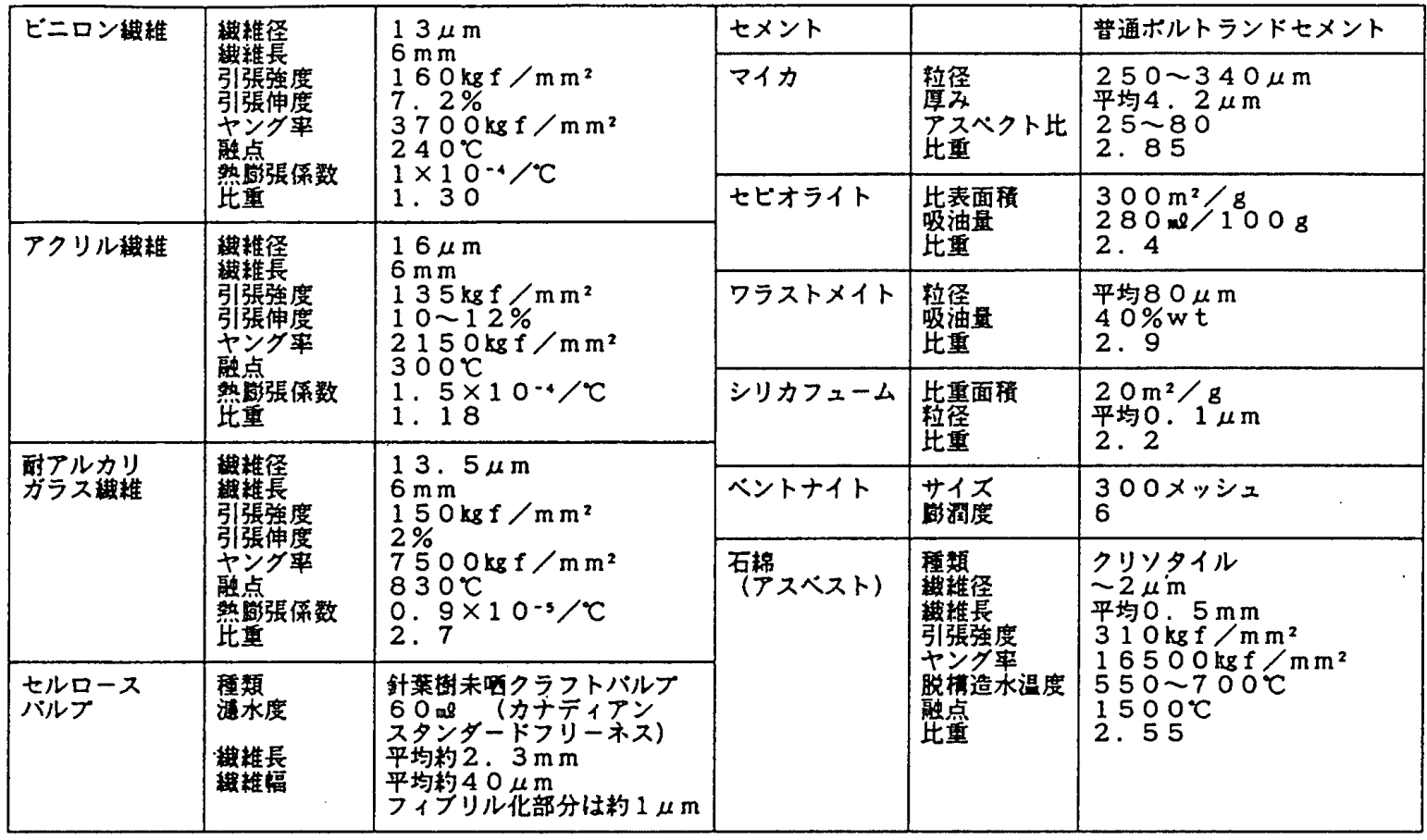

表一3 試験体の調合

\begin{tabular}{|c|c|c|c|c|c|c|c|c|c|c|c|}
\hline \multirow{2}{*}{$\begin{array}{c}\text { 試験体 } \\
\text { 種類 }\end{array}$} & \multicolumn{4}{|c|}{ 補強緎維（wt\%） } & \multirow{2}{*}{$\begin{array}{l}\text { セメント } \\
(\text { wt\%) }\end{array}$} & \multirow{2}{*}{$\begin{array}{r}\text { パルプ } \\
(\text { wt\%) }\end{array}$} & \multicolumn{5}{|c|}{ 無機添加材（wt\%) } \\
\hline & $t^{*}=a^{\prime}$ & 了讧N & 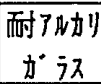 & 石綿 & & & 仂 & $\begin{array}{c}\text { té } t ; 1 \\
1\end{array}$ & $\begin{array}{c}\text { 7ixㄱ1 } \\
1\end{array}$ & $\begin{array}{c}\text { シ饬7 } \\
4\end{array}$ & $\begin{array}{c}1 \%+1 \\
1\end{array}$ \\
\hline$V P-1$ & 1.5 & - & - & - & 84.0 & 3.0 & 10.0 & 1.5 & - & - & - \\
\hline$V P-2$ & 1.2 & - & - & 2.0 & 82.8 & 2.0 & 2.0 & 1.0 & 6.0 & 3.0 & - \\
\hline$V P-3$ & 1.0 & - & - & 4.0 & 81.5 & 1.5 & - & - & 8.0 & 4.0 & - \\
\hline $\mathrm{AP}-1$ & $\overline{-}$ & 1.5 & - & $\overline{-}$ & 80.5 & 3.0 & 10.0 & - & - & - & 5.0 \\
\hline $\mathrm{AP}-2$ & - & 1.5 & - & 2.0 & 78.5 & 3.0 & 10.0 & - & - & - & 5.0 \\
\hline $\mathrm{AP}-3$ & - & 1.5 & - & 4.0 & 76.5 & 3.0 & 10.0 & - & - & - & 5.0 \\
\hline $\mathrm{GP}-1$ & 0.25 & - & 1.5 & - & 89.25 & 4.0 & 5.0 & - & - & - & - \\
\hline$G P-2$ & 0.25 & - & 1.5 & 2. 0 & 87.25 & 4.0 & 5.0 & - & - & - & - \\
\hline$G P-3$ & 0.25 & - & 1.5 & 4.0 & 85.25 & 4.0 & 5.0 & - & - & - & - \\
\hline
\end{tabular}


らにマイカ, アクリル繊維, セメント, ベントナイトを 投入して 10 分間摫找した。スラリーをチェストへ移し， 5 分後に抄造を開始した。なお抄造性向上のため凝集剤 を加え, 抄板生板はビニールで包み, 室内で 28 日間養 生した。

耐アルカリガラス瀻維を主たる補強瀻維とする $\mathrm{GP}-1,2 ， 3$ の試験体は，丸網抄造機により作製した。， 水とパルプをパルパーにより十分に摜汼した後，ガラス 瀻維を除く固形分を投入して摫汼し，最後に耐アルカリ ガラス繊維を投入して摫挥した。スラリーをチェストに 移して抄造を行った。最後に耐アルカリガラス繊維を投 入するのは，耐アルカリガラス繊維の摫汼による破損を 少なくするためである。なお抄造性向上のため高分子凝 集剤を添加した。

以上のいずれの試験体の作製においても抄造効率は良 く，これらの調合による製品はスレートの製造に使われ ている抄造の実機で製造できると考えられた。

基準品の石綿スレートと既開発品は，実際の製造ライ ンからサンプリングした。

\section{4. 性能評価の試験方法}

難燃性，曲げ強さ，耐衝撃性および耐凍結融解性につ いて性能試験を行った。表一4に試験項目ごとの試験体 寸法と試験体数を示す。

難燃性は，建築基準法施行令第 108 条の 2 による不燃 材料の指定（昭和 45 年 12 月 28 日建設省告示 1828 号） に従い，表面試験と基材試験を行った。表面試験では, 加熱中と加熱後の試験体の変形の外観観察, 排気温度曲 線，発煙係数，残炎時間，龟裂，加熱減量を測定し，基 材試験では，試験体挿入後の炬内最高温度，加熱減量を 測定した。

曲げ強さは，JIS A 1408 建築用ボード類の曲げ試験 方法に準じて試験した。試験体を温度 $20^{\circ} \mathrm{C}$ ，湿度 $50 \%$ の試験室に 7 日間以上静置して, 試験体の質量, 厚さ, 幅および長さを測定した後，インストロン万能試験機を 使用して支点間距離 $100 \mathrm{~mm}$, 載荷速度 $0.5 \mathrm{~mm} / \mathrm{min}$ で

表一4 試験体寸法と数量

\begin{tabular}{|c|c|c|c|}
\hline \multicolumn{2}{|c|}{ 試験項目 } & 寸法 $\mathrm{mm}$ & 数量 \\
\hline \multirow[t]{2}{*}{ 曲げ強さ } & 平行方向 & \multirow{2}{*}{$40 \times 160 \times 6$} & 3 \\
\hline & 直角方向 & & 3 \\
\hline \multicolumn{2}{|c|}{ 耐凍害性 } & $40 \times 160 \times 6$ & 3 \\
\hline \multicolumn{2}{|c|}{ 衝擊 } & $300 \times 300 \times 6$ & 3 \\
\hline \multirow[t]{2}{*}{ 燃焼性 } & 表面試験 & $220 \times 220 \times 6$ & 3 \\
\hline & 基材試験 & $40 \times 40 \times 48$ & 3 \\
\hline
\end{tabular}

試験体中央を最大荷重に達するまで加力し，荷重-クロ スヘッド移動距離の曲線を記録した。曲げ強さのほか最 大荷重時のたわみ，比重，含水率を測定した。

耐衝撃性は，JIS A 5403 石綿スレートに従って試験 した。

耐凍害性は, JIS (案) 外壁材料の耐凍害性試験方法 の片面吸水凍結融解法に従った。試験体を $20^{\circ} \mathrm{C}$ の清水 中に 24 時間浸漬した後, 表面の水分を布で拭き取り， 注水したフェルトの上に置き，プログラム付恒温恒湿槽 で, $-18^{\circ} \mathrm{C} \sim 10^{\circ} \mathrm{C}$ の温度域の凍結融解を 200 サイクル 行った。槽内の盜度管理はフェルトの間に置いた熱電対 で行い，加熱および冷却をそれぞれ 2 時間で行い，1 1 サ イクル所要時間を 4 時間とした。100および 200 サイク ル後に, 試験体の割れ, 亀裂, 剥離の有無を目視観察し, 試験体を $20^{\circ} \mathrm{C}$ の清水中に 24 時間浸せきした後, 厚さ および質量の変化率を測定した。200サイクル後では曲 げ試験を行い，曲げ強さおよび最大荷重時のたわみを測 定した。曲げ試験後に試験体を $105^{\circ} \mathrm{C}$ の乾燥機に入れ， 重量が一定になるまで乾燥し，質量を測定して含水率を 求めた。

\section{5. 性能評価の試験結果と考察}

\section{1 比重と含水率}

成形して数週間置いた後，温度 $20^{\circ} \mathrm{C}$ 湿度 $50 \% \mathrm{RH}$ の試験室に 7 日間以上静置した試験体の比重を図一1
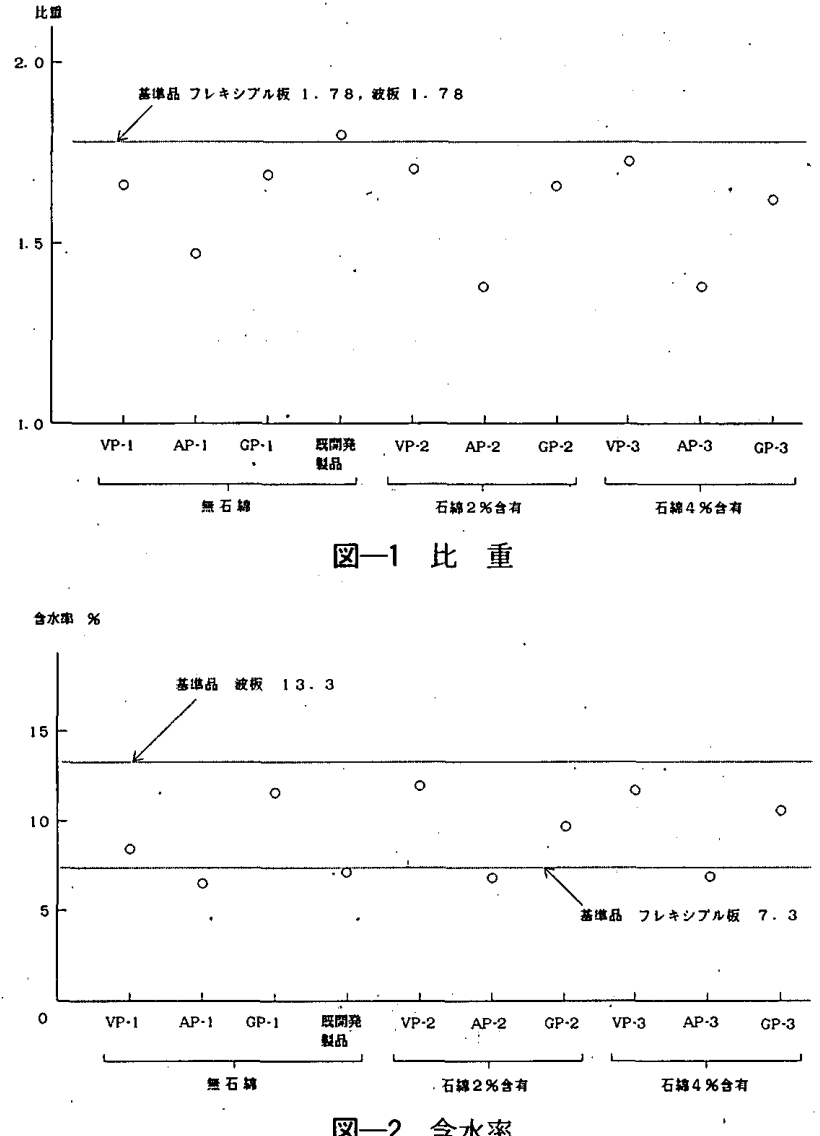

図一2 含水率 
に，そのときの含水率を図一 2 に示す。

比重は AP-1, 2, 3 の試験体が比較的小さく, その他 の試験体の比重は既開発製品を除いて基準品のフレキシ ブル板と波板よりやや小さい。

含水率は，基準品の波板とフレキシブル板の值の間に ほぼ入っており，GP-1，3，VP-2，3 の試験体がやや大 きく，それ以外は $10 \%$ 以下である。JIS A 5403 石綿ス レートでは, フレキシブル板の場合に含水率を $10 \%$ 以 下になるまで乾燥して出荷すると規定している。

\section{2 難然性}

表面試験の結果を表一 5 に，基材試験の結果を表一 6 に示す。

表面試験の合格と不合格は，3体の試験体すべてが次 の 5 つの項目に適合するか否かで判定した結果である。

。防火上著しく有害な変形が無い。

。全厚の $1 / 10$ 以上の幅の亀裂が無い。

。温度時間面積が 0 である。

。発炎係数 CA が 30 以下である。
・残炎時間が 30 秒末満である。

基材試験の合格と不合格は，3体の試験体すべての温 度差が $50^{\circ} \mathrm{C}$ 以下であるとき合格，そうでないとき不合 格として判定した結果である。

無石綿試験体は 3 種類の試験体のいずれも表面試験と 基材試験の両方に合格している。石綿を含有する試験体 では，いずれも基材試験に合格するが，VP-2 と VP-3 の試験体が全厚の $1 / 10$ 以上の幅の亀裂を発生するため 表面試験に不合格となっている。不合格となった理由は， コストの低減を目的として表一 3 に示すようにビニロ ン, パルプ, セピオライト, マイカの量を減じて, ワラ ストナイト，シリカフュームの量を増やした調合とした ためであり，マイカの増量等の調整により合格すること は可能と思われる。

\section{3 曲げ強さとたわみ}

抄造方向に平行な方向をスパンとした曲げ試験による 曲げ強さを図一 3 に,たわみを図一 4 に示す。曲げ強さは, いずれの試験体も基準品のフレキシブル板と波板よりや

表一5 難燃性試験の表面試験結果

\begin{tabular}{|c|c|c|c|c|c|c|c|c|c|c|c|c|}
\hline \multirow[b]{2}{*}{ 項 目 } & \multicolumn{4}{|c|}{ 無吕綿 } & \multicolumn{3}{|c|}{ 石綿 $2 \%$ 含有 } & \multicolumn{3}{|c|}{ 石綿 $4 \%$ 含有 } & \multicolumn{2}{|c|}{ 基準品 } \\
\hline & $V P-1$ & $\mathrm{AP}-1$ & $G F-1$ & $\begin{array}{l}\text { 既開発 } \\
\text { 製品 }\end{array}$ & VP-2 & $A P \cdot 2$ & $G P \cdot 2$ & $V F-3$ & $A P-3$ & GP-3 & 波板 & $\begin{array}{l}\text { フレキシ } \\
\text { ブル板 }\end{array}$ \\
\hline $\begin{array}{l}\text { 防火上著しく } \\
\text { 有害な变形 }\end{array}$ & \multicolumn{12}{|c|}{ それぎれ3体の試験体いずれも無し } \\
\hline \multirow{3}{*}{$\begin{array}{r}\text { 智巾一長さ } \\
\mathrm{mm}\end{array}$} & $0-0$ & $0-0$ & $0-0$ & $0-0$ & $0-0$ & $0-0$ & $0-0$ & $0-0$ & $0-0$ & $0-0$ & $0-0$ & $0-0$ \\
\hline & $0-0$ & $0-0$ & $0-0$ & $0-0$ & $0.5-197$ & $0-0$ & $0-0$ & $0-0$ & $0-0$ & $0-0$ & $0-0$ & $0-0$ \\
\hline & $0-0$ & $0-0$ & $0-0$ & $0-0$ & $1.0-190$ & $0-0$ & $0-0$ & $1.0-190$ & $0.1-154$ & $0-0$ & $0.3-125$ & $0-0$ \\
\hline $\begin{array}{l}\text { 温度時間面䅡 } \\
{ }^{\circ} \mathrm{C} \times \min \end{array}$ & \multicolumn{12}{|c|}{ それミれ3体の試験体いずれも } \\
\hline & 1 & 0.5 & 0 & 0 & 1 & 4 & 0 & 1 & 1 & 0 & 0 & 0 \\
\hline 発㖶係数 CA & 1 & 1 & 0 & 0.5 & 0 & 2 & 0 & 1 & 0 & 1 & 0 & 0.5 \\
\hline & 1 & 1 & 0.5 & 0.5 & 1.5 & 1.5 & 0 & 1 & 0 & 0 & 0 & 0 \\
\hline 残炎時間 sec & \multicolumn{12}{|c|}{ こ扎气れ れ 体の試験体いず机も } \\
\hline 表面試験の合否 & 合格 & 合格 & 合格 & 合格 & 不合格 & 合格 & 合格 & 不合格 & 合格 & 合格 & 合格 & 合格 \\
\hline
\end{tabular}

表一6 難然性試験の基材試験結果

\begin{tabular}{|c|c|c|c|c|c|c|c|c|c|c|c|c|}
\hline \multirow[b]{2}{*}{ 項目 } & \multicolumn{4}{|c|}{ 無石綿 } & \multicolumn{3}{|c|}{ 石綿 $2 \%$ 含有 } & \multicolumn{3}{|c|}{ 石綿4\%含有 } & \multicolumn{2}{|c|}{ 基準品 } \\
\hline & $V P-1$ & $A P-1$ & $G P-1$ & $\mid \begin{array}{l}\text { 既開発 } \\
\text { 製品 }\end{array}$ & $V P-2$ & AP-2 & GP-2 & VP-3 & $A P \cdot 3$ & $\mathrm{GP}-3$ & 波板 & $\begin{array}{l}\text { フキシ } \\
\text { ブル板 }\end{array}$ \\
\hline 温度差 ${ }^{\circ} \mathrm{C}$ & $\begin{array}{l}36 \\
34 \\
35\end{array}$ & $\begin{array}{l}50 \\
45 \\
50\end{array}$ & $\begin{array}{l}30 \\
35 \\
32\end{array}$ & $\begin{array}{l}35 \\
40 \\
42\end{array}$ & $\begin{array}{r}38 \\
30 \\
28\end{array}$ & $\begin{array}{l}35 \\
48 \\
41\end{array}$ & $\begin{array}{l}29 \\
36 \\
28\end{array}$ & $\begin{array}{l}23 \\
33 \\
30\end{array}$ & $\begin{array}{l}40 \\
38 \\
45\end{array}$ & $\begin{array}{l}31 \\
35 \\
32\end{array}$ & $\begin{array}{l}18 \\
25 \\
25\end{array}$ & $\begin{array}{l}15 \\
20 \\
18\end{array}$ \\
\hline 加熱減量 $g$ & $\begin{array}{l}18.9 \\
19.1 \\
18.7\end{array}$ & $\begin{array}{l}18.0 \\
17.4 \\
17.6\end{array}$ & $\begin{array}{l}18.7 \\
18.5 \\
18.9\end{array}$ & $\begin{array}{l}16.0 \\
17.0 \\
16.7\end{array}$ & $\begin{array}{l}18.5 \\
18.2 \\
18.4\end{array}$ & $\begin{array}{l}13.9 \\
14.1 \\
14.0\end{array}$ & $\begin{array}{l}17.1 \\
19.6 \\
18.6\end{array}$ & $\begin{array}{l}17.0 \\
16.6 \\
17.8\end{array}$ & $\begin{array}{l}14.9 \\
15.8 \\
15.3\end{array}$ & $\left|\begin{array}{l}17.2 \\
19.4 \\
20.6\end{array}\right|$ & $\begin{array}{l}21.8 \\
17.9 \\
18.7\end{array}$ & $\begin{array}{l}18.3 \\
18.6 \\
18.7\end{array}$ \\
\hline 基材試験の合否 & 合格 & 合格 & 合格 & 合格 & 合 格 & 合格 & 合格 & 合格 & 合格 & 合格 & 合格 & 合格 \\
\hline
\end{tabular}




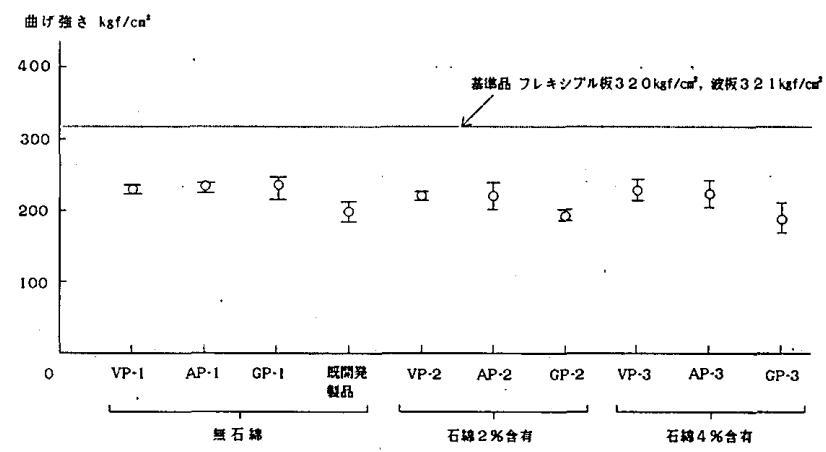

図一3 曲げ強さ（抄造方向に平行な方向をスパンとした曲げ試 験による)

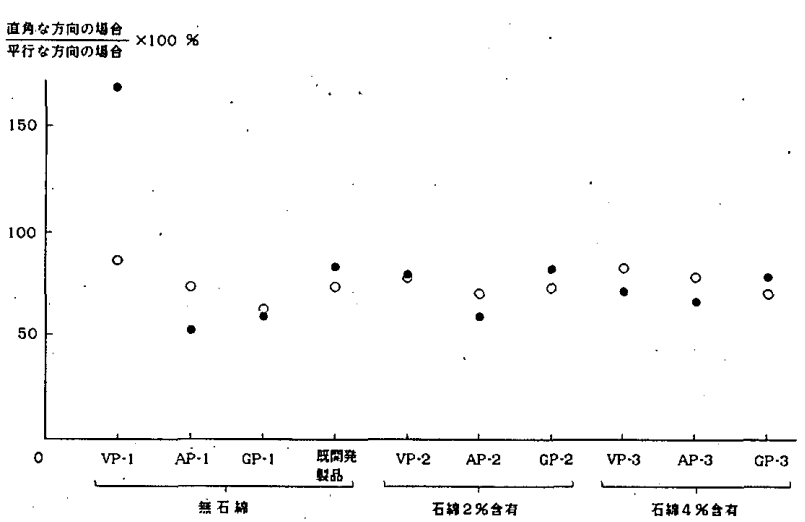

図一5抄造方向に平行な方向をスパンとした場合と直角な方向 をスパンとした場合の曲げ試験の曲げ強さの比率（○で 示す）をたわみの比率（○で示す）

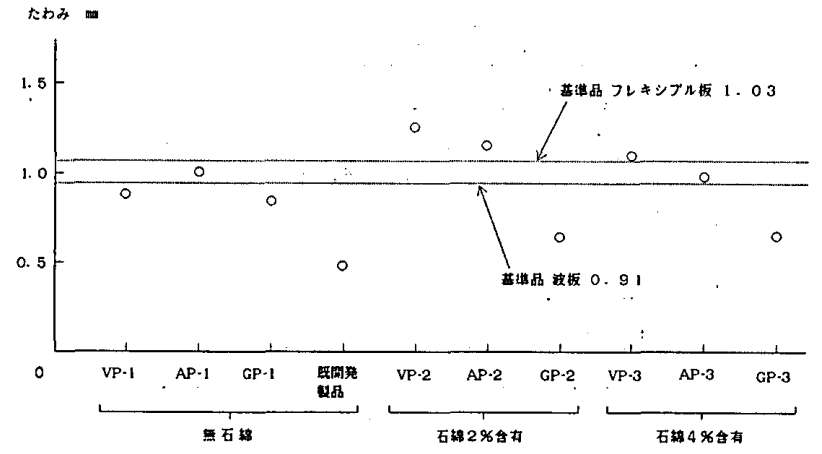

図一4曲げ試験のたわみ（抄造方向に平行な方向をスパンとし た曲げ試験による)

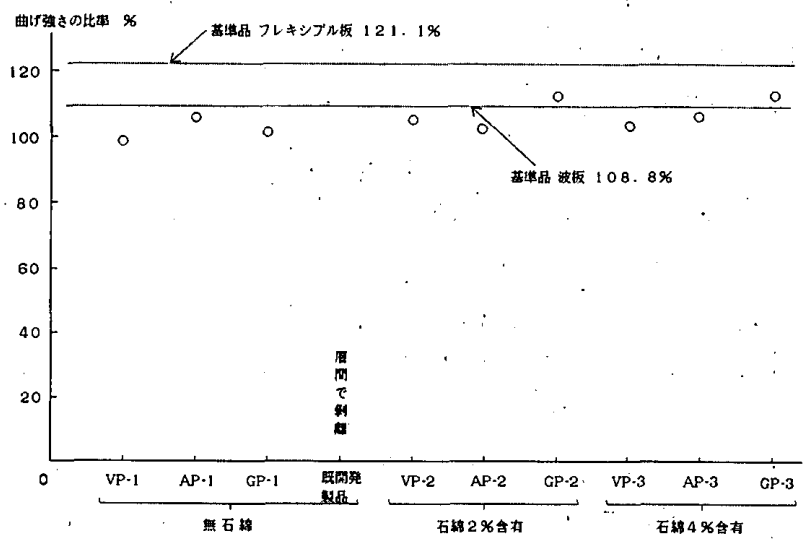

図一6凍結融解 200 サイクル綝返し後の曲げ強さの初めの曲げ。 強さに対する比率

表一7凍結融解繰返し後の質量と厚さ（凍結融解繰返し前を 100 とする)

\begin{tabular}{|c|c|c|c|c|c|c|c|c|c|c|c|c|c|}
\hline \multirow[b]{2}{*}{ 項 目 } & \multirow{2}{*}{$\begin{array}{l}\text { 凍結融 } \\
\text { 解のサ1 } \\
\text { 妆数 }\end{array}$} & \multicolumn{4}{|c|}{ 無石綿 } & \multicolumn{3}{|c|}{ 石綿 $2 \%$ 含有 } & \multicolumn{3}{|c|}{ 石綿 $4 \%$ 含有 } & \multicolumn{2}{|c|}{ 基準品 } \\
\hline & & $V P-1$ & $\mathrm{AP}^{-1} 1$ & $G F-1$ & $\begin{array}{l}\text { 既開発 } \\
\text { 製品 }\end{array}$ & VP-2 & $A P-2$ & GP-2 & $V P \cdot 3$ & $A P-3$ & GP-3 & 波板。 & $\begin{array}{l}\text { つキシ } \\
\text { ブル板 }\end{array}$ \\
\hline \multirow{2}{*}{ 筫量 } & 100 & 101.7 & 100.0 & 101.6 & 101.8 & 101.4 & 100.9 & 101.0 & 101.0 & 100.8 & 101.0 & 100.7 & 100.5 \\
\hline & 200 & 102.3 & 100.8 & 100.5 & 層間剝翯 & 101.3 & 101.0 & 99.7 & 100.5 & 101.3 & 100.4 & 99.7 & 100.8 \\
\hline \multirow{2}{*}{ 厚さ } & 100 & 100.0 & 100.4 & 100.0 & 103.7 & 100.2 & 100.3 & 100.3 & 100.0 & 99.9 & 100.0 & 100.3 & 99.7 \\
\hline & 200 & 100.3 & 100.6 & 100.0 & 僵間䣋離 & 99.8 & 100.3 & 100.1 & 99.5 & 100.0 & 99.9 & 100.0 & 100.3 \\
\hline
\end{tabular}

や低い。だわみは，GP-2 と 3 の試験体と既開発製品が 比較的小さいが, それ以外の試験体は基準品のフレキシ ブル板と波板に近い值である。

図一5は，抄造方向に垂直な方向をスパンとした場合 と，抄造方向に平行な方向をスパンとした場合との比較 である。○印で示される曲げ強さの割合は，60～ $80 \%$ 程度である。JIS A 5403 石綿スレートのフレキシブル 板は，この割合が約 $70 \%$ である。

\section{4 耐衝擊性}

すべての試験体について, 衝撃試験で異常はなかった。

\section{5 而凍結融解性}

凍結融解繰返し後の質量と厚さを表一7. に，含水率を 表一8に示す。凍結融解繰返し後の外観調查では，既開 発製品の試験体は層間で剝離したが，他の試験体は外観 に異常がない。層間剥離をしている既開発製品を除いて， いずれも凍結融解繰返しによる質量と厚さの変化は小さ い。繰返し前の含水率は, 24 時間静水中に浸せきした 試験体で測定した值であり，吸水率に相当する。AP-3 の試験体の吸水率が比較的大きいが，それ以外の試験体 の吸水率は $21 〜 24 \%$ 程度の範囲にある。JIS A 5403 石 
表一8 凍結融解 200 サイクル繰返し前と後の含水率

\begin{tabular}{|c|c|c|c|c|c|c|c|c|c|c|c|c|}
\hline \multirow[b]{2}{*}{ 項目 } & \multicolumn{4}{|c|}{ 無石綿 } & \multicolumn{3}{|c|}{ 石綿 $2 \%$ 含有 } & \multicolumn{3}{|c|}{ 石綿 $4 \%$ 含有 } & \multicolumn{2}{|c|}{ 基準品 } \\
\hline & $V P-1$ & $A P-1$ & $G F-1$ & $\begin{array}{l}\text { 既開発 } \\
\text { 製品 }\end{array}$ & $V P-2$ & $\mathrm{AP}-2$ & $\mathrm{GP}-2$ & $V P-3$ & $A F-3$ & $\mathrm{GP}-3$ & 波板 & $\begin{array}{l}\text { フレキ } \\
\text { ブル板 }\end{array}$ \\
\hline 前の含水率 $\%$ & 21.1 & 23. 2 & 21.9 & 20.7 & 23.8 & 22.2 & 23.0 & 21.1 & 28.1 & 24.1 & 23.1 & 20.5 \\
\hline 後の含水率 \% & 23.7 & 23. 8 & 21.8 & $\begin{array}{l}\text { 涌間 } \\
\text { 剝離 }\end{array}$ & 25.2 & 29.0 & 21.3 & 21.9 & 29.2 & 25.9 & 23.3 & 20.4 \\
\hline
\end{tabular}

綿スレートのフレキシブル板では, 吸水率は $22 \%$ 以下 である。

凍結融解 200 サイクル絽返し後の曲げ強さの初めの曲 げ強さに対する比率を図一6に示す。凍結融解絽返しに よる曲げ強さの低下はほとんどない。基準品のフレキシ ブル板と波板に比べると, 凍結融解繰返し後の試験体の 曲げ強さの比率はやや低い傾向にある。

\section{6 代替材料の安全性}

石䄸代替に用いた材料は, 表一 2 に示したような寸法 形状をしておりここれらの材料の安全性について現在の ところ次のように考えられる。

ビニロン繊維，アクリル繊維および耐アルカリガラス 繊維は，呼吸で吸入される限度の $5 \mu \mathrm{m}$ 以上の径があり， 紩に裂けて細くなる性質がないと報告されているので, 吸入による疾病には安全である。セルロースパルプは, フィブリル化した部分が遊離すると吸入性の寸法になる が，人体への有害性が認められない。

マイカ, セピオライト,ワラストナイト,シリカフュー ムおよびベントナイトは，吸入される大きさのものが含 まれるので，その粉じんを㧕制する必要がある。これら の材料の使用量が少ない場合は，作業場所の空気を清净 に保つ集じん装置により,人体への安全性を保つように, 粉じんを抑制することができる。

\section{6. 結 論}

抄造性を高めるために高吒解したセルロースパルプを 用い，必要な強度を得るためにビニロン繊維，アクリル 繊維, または耐アルカリガラス繊維を入れ, 耐熱性や化 学的安定性を向上するための鉱物物質をフィラーとして 添加することにより，次のような性能を有する無石綿の スレートを抄造で製造することができる。

・表面試験と基材試験に合格し必要な難然性を有する。

・基準品のフレキシブル板と波板に比べて，曲げ強さは やや低く，比重はやや小さい。したがって同じ厚さの板 の場合は, 従来の石綿スレートより耐力が少し低い。ま た同じ重量の板の場合は, 従来の石綿スレートに近い耐 力になる。

・JIS の石綿スレートの $6 \mathrm{~mm}$ 厚さのフレキシブル板で 規定される強度の基準値に相当する $292 \mathrm{kgf} / \mathrm{cm}^{2}$ の曲げ
強さに比べて，やや低い曲げ強さである。

・たわみは，基準品の石綿スレートと同程度である。

・耐衝撃性は十分な性能がある

・ 200 サイクルの耐凍結融解試験で, 性能低下は生じな い。基準品のフレキシブル板と波板に比べて, 耐凍結融 解性はやや劣る。

・乾燥状態における含水率は, ビニロン繊維とアクリル 繊維を補強瀻維とする場合は $10 \%$ 以下である。

・吸水率は, 石綿スレートのフレキシブル板の規格値の $22 \%$ 程度である。

石綿を $2 \%$ または $4 \%$ 入れた試験体の成形後の性能 は無石綿試験体と同程度であり, 今回の性能試験の項目 については，石綿を少量混入したことで明確な差異は認 められない。なお，石綿を少量混入すると抄造性が向上 しコストが低減される可能性がある。

人体への安全性について, セルロース瀻維, ビニロン 繊維, アクリル繊維は有害性を示唆する文献が無く，ま た耐アルカリガラス繊維は，呼吸で吸入される限度の 5 $\mu \mathrm{m}$ 以上の径があり縦に裂けて細くなる性質がないの で，石綿で問題になっている吸入による疾病を起こさな い。

\section{謝 辞}

本研究は石綿代替製品調査研究本委員会（委員長岸谷 孝一, 委員平居孝之, 東 敏明, 高橋泰一, 長田直俊, 田村伊行, 丸一俊雄, 今泉正達, 中山 勉, 草野 武, 滝川充朗, 土谷 澄, 福渡 豊, 湯村崇男), 調查分科 会（主査 平居孝之，委員前田孝一，仲座政宏，遊佐秀 逸, 佐藤二一, 高橋康朗, 乙黒利和, 長岡秀光, 井上忠 泰, 服部純雄, 日笠純一, 十河英二, 上田富士男, 草津 悟昭, 溝口和雄, 荒木 卓, 堀内盛夫, 武田洋一, 安藤 文雄, 上田 弘, 計 和弘), 建材試験センター事務局 (森 幹芳, 高野美智子）で行ったものであり，試験の実施に おいては十河英二 (東レ, 繊維新事業部), 日笠純一(ク ラレ，産資・リビング事業本部），計 和弘（住友金属, 末来技術研究所), 長岡秀夫 (スレート協会, 浅野スレー ト）の各氏に尽力をいただいた。関係各位に感謝の意を 表します。 


\section{参考文献}

1）環境厅大気保全局企画課：アスベスト代替品の開発及び 普及状況に関する調查中間報告,. 昭和 63 年 3 月

2）内田京治：ノン・アスベスト建材の開発と石綿処理技術, 建築仕上技術 Vol.13，No.153，pp.116 117，1988.4

3）本橋健司：アスベスト代替建材開発の動向，建築仕上技 術Vol.15, No. 177, pp. 44 47, 1990.4

4）久保田昭：各産業分野でのアスベスト代替化の動向, 建 築仕上技術 Vol. 15, No. 177，pp. 48～51，1990.4

5）遊佐秀逸：米国におけるアスベスト代替材料開発の動向, 建築仕上技術 Vol. 15, No. 177, pp. 52 54, 1990.4

6）日本石綿協会：石綿に関する海外調查アンケート回答結 果, 1989.5

7）日笠紝一：アスベスト規制と代替素材の開発，化学経済, pp. $23 \sim 30,1989.7$

8）日笠純一：アスベスト代替高分子材料，第 38 回高分子夏 期大学, 講演要旨集, pp. 150 153，1990.7

9）溝辺昭雄：アスベスト代替用織維一スレート板用途を中 心にして一, 化学と工業第 41 巻, 第 6 号, pp. 121 123, 1988

10）未来工学研究所：石綿代替品開発動向調查報告書，環境 庁大気保全局大気規制課監修, 1990.3

11) Lohrer W. : Asbest-Ersatzstoffe, Staub-Reinhaltung der Luft 49, pp. $61 \sim 66,1989$

12) Lohrer W. : Ersatzstoffe fur Asbest, Staub-Reinhaltung der Luft 40, pp. 210 217, 1980

13) Studinka J. B. : Asbestos substitution in the fibre cement industry, The International Journal of Cement Composites and Lightweight Concrete, Volume 11, No. 2, pp. 73 78, 1989.5

14) Hodgson A.A. : ALTERNATIVES TO ASBESTOS AND ASBESTOS PRODUCTS, ANJALENA PUBLICATIONS LTD, 1985.1

15）橋本隆治ほか 2 名：セルロース㵶維の耐久性, 石綿スレー 卜協会，技術部会論文集第 33 集，pp. 13～22，1990.6

16) Bentur A., et al: The microstructure and ageing of cellulose fibre reinforced cement composites cured in a normal environment, The International Journal of Cement Composites and Lightweight Concrete, Vol.11, No. 2, pp. $99 \sim 109$, 1989.5

17) Bentur A., et al: The microstructure and ageing of cellulose fibre reinforced autoclaved cement composites, The International Journal of Cement Composites and Lightweight Concrete, Vol.11, No.2, pp.111 115, 1989.5

18) Akers S. A.S. et al : Micromechanical studies of fresh and weathered fibre cement composites, Part 1 : Dry testing, The International Journal of Cement Composites and Lightweight Concrete, Vol.11, No.2, pp. 117 124, 1989.5

19) Tait R. B., et al : Micromechanical studies of fresh and weathered fibre cement composites. Part 2 : Wet testing,
The International Journal of Cement Composites and Lightweight Concrete, Vol.11, No.2, pp. 125 131, 1989.5

20) Akers S. A. S, et al : ET Long term durability of PVA reinforcing fibres in a cement matrix, The International Cement Composites and Lightweight Concrete, Vol.11, No. 2, pp. 79 91, 1989.5

21）乾 修郎, 寺本 博：石綿代替㵶維の研究（ビニロンと 耐アルカリ性ガラス瀻維の比較)，石綿スレート協会技術 部会論文集第 27 集, pp. 14 21，1984.6

22) Hahne D. H., et al : The asbestos alternative, Textile Tech: International, pp. 57 60, 1990

23）松山保秀, 田口裕之：けいカル板に於ける石綿代替䋐維 の検討，石綿スレート協会技術部会論文集第 32 集, pp. 8〜 16, 1989. 6

24）松山保秀, 多田裕昭：合成繊維および耐アルカリ性ガラ ス繊維について（第 2 報），石綿スレート協会技術部会論 文集第 26 集, pp. $46 \sim 57,1983.6$

25）内藤恒雄ほか 2 名：Asbestos free 石綿スレート超大波の 検討，石綿スレート協会技術部会論文集第 31 集, pp. 1 $\sim 5,1988.6$

26) Blais R.A., et al : CHARACTERISTICS OF FIBRES USED IN CEMENT AS ALTERNATIVES TO ASBESTOS, Technical Paper, THE ASBESTOS INSTITUTE, Montreal, Quebec, Canada, 1985.9

27）仲座政宏ほか 2 名：環境測定技術者のための石綿および 代替綫維写真集，リコーテクノリサーチ，1989.9

28) Peto J. : FIBRE CARCINOGENESIS AND ENVIRONMENTAL HAZARD, Institute of Cancer Research, Sutton, Surrey, UK, 1989

29) WHO, : WHO Environmental Health Critera 77, MAN= MADE MINERAL FIBERS, 1988

30) Doll R. : MINERAL FIBRES IN THE NONOCCUPATIONAL ENVIRONMENT : CONCLUDING REMARKS, Imperial Cancer Research Fund Cancer Epidemiology and Clinical Trials Unit, Radecliffe Infirmary, Oxford, UK., International Agency for Research on Cancer (IARC), Lyon, France, No. 90, 1989

31) ILO : Working paper on safety in the use of mineral and synthetic fibers, Meeting of Experts on Safety in the Use of Mineral and Synthetic Fibers, International Labour Office, Geneva, 1989

32）日本石綿協会安全衛生委員会：せきめんの素顔，1988.4

33）安達修一, 竹本和夫：石綿代替物質の生体影響, 大気污 染学会, pp. 188 189, 1990. 10

34) Dunnigan J., : KNOWN BIOLOGICAL ACTIVITY OF SELECTED ASBESTOS SUBSTITUTES, A REVIEW OF RECENTLY PUBLISHED DATA, Scientific Paper, THE ASBESTOS INSTITUTE, Montreal, Quebec, Canada 1987.12

（1992 年 2 月 10 日原稿受理, 1992 年 8 月 25 日採用決定） 